\title{
The Impact of Board Characteristics on Co-operative Reputation From the Lense of Resource-Based View Theory (RBVT)
}

\author{
Aida Maria Ismail ${ }^{1}$, Siti Muliyana $\mathrm{Ahmadi}^{2}$, Normahiran Yatim $^{1} \&$ Puteh Mariam Ismail $^{1}$ \\ ${ }^{1}$ Faculty of Accountancy, Universiti Teknologi MARA, Selangor Campus, Malaysia \\ ${ }^{2}$ Malaysian Co-operative Societies Commission, Malaysia \\ Correspondence: Aida Maria Ismail, Faculty of Accountancy, Universiti Teknologi MARA, Selangor Campus, \\ Malaysia. E-mail: aida430@uitm.edu.my
}

Received: March 16, 2020

Accepted: April 30, 2020

Online Published: June 29, 2020

doi:10.5430/ijfr.v11n3p43

URL: https://doi.org/10.5430/ijfr.v11n3p43

\begin{abstract}
Numerous studies on corporate governance proposed the connection of boards' characteristics on firm performance and reputation. However, the results are mixed and limited research in the co-operatives context has creates a great interest to fill the conspicuous gap. This study seeks to examine the potential relationship between board characteristics and co-operative reputation in Malaysia from the perspective of resource-based view theory (RBVT). Hence, multiple regressions were conducted to analyze the relationship between co-operatives reputation with the respect of Top 100 Co-operatives Index and board characteristics in terms of board size, ethnic diversity, gender diversity, age diversity and education diversity in this study. The sample is composed of 61 listed co-operatives in the Top 100 Co-operatives Index for the three-consecutive year during the period 2015 to 2017. Reputation data were obtained from Top 100 Co-operative Index that published at Malaysia Co-operative Societies Commission (MCSC) website. While, the data of board characteristics and co-operative size on log of total assets which lagged by a year were extracted from MCSC's INFOKOP system that provides both financial and non-financial data. The results found that Malaysian co-operatives that appear high up in terms of ranking in the reputation MCSC index tend to have a greater proportion of high educational directors on their board. Other board characteristics including board size, ethnic diversity, gender diversity and age diversity were not associated with the reputation of co-operatives. This generally can be explained that different types of law, geography, historical background, cultural environment and other factors may affect composition and diversity; and particularly the board in co-operative societies. Findings of this study provide insights into potential strategies in relation to corporate governance towards improving co-operative's values and indirectly help the government in achieving the national economic goals.
\end{abstract}

Keywords: board characteristics, board diversity, reputation, capabilities, resource-based view theory (RBVT)

\section{Introduction}

The co-operative sector plays an important role in economic development by creating job and business opportunities, improving the quality of life and helping to reduce poverty in Malaysia (Mahajar \& Mohd Yunus, 2005). According to Hammad Ahmad Khan, Yaacob, Abdullah, \& Abu Bakar Ah (2016), co-operatives not only benefited its members but also played an important role in improving the standard of living among the low and middle-income communities, which indirectly acts as a distribution tool for national wealth to eradicate poverty. In order to elucidate its important role, the co-operative sector has been targeted as the third engine of national economic development, together with the public and private sectors in Malaysia.

The National Co-operative Policy 2011-2020 (NCP II) outlines initiatives for the transformation of the co-operatives movement to become more competitive and active players in the national economy with the main objective to increase their contribution to the Gross National Product (GNP). Co-operatives are expected to contribute 5\% GNP by year 2013 and 10\% GNP by year 2020. However, in 2013, it was reported by the Malaysia Co-operative Societies Commission (MCSC) that a total of 10,914 of co-operatives registered but failed to achieve the goals set for 5\% GNP. This was due to the low contribution of co-operative sector towards economic growth compared to public and private sectors. In response to that, NCP II has been revised to strengthen the co-operatives strategic plan for the next five-years (2015 to 2020) and to reset the main objective in increasing the co-operative's contribution to GNP up to RM50 billion in year 2020. 
Table 1 presents the statistics of the co-operative movement in Malaysia which include number of co-operatives, number of members, share capital, asset and turnover from year 2011 to 2017 with the estimated turnover in year 2020.

Table 1. Statistics of co-operative movement in Malaysia from 2011 to 2017

\begin{tabular}{|c|c|c|c|c|c|c|}
\hline \multirow[t]{2}{*}{ Year } & \multirow{2}{*}{$\begin{array}{l}\text { Number of } \\
\text { co-operative }\end{array}$} & \multirow{2}{*}{$\begin{array}{l}\text { Number } \\
\text { members }\end{array}$} & \multirow[t]{2}{*}{ of } & \multirow{2}{*}{$\begin{array}{l}\text { Share Capital } \\
\text { (RM' billion) }\end{array}$} & \multirow{2}{*}{$\begin{array}{l}\text { Assets } \\
\text { (RM' billion) }\end{array}$} & \multirow{2}{*}{$\begin{array}{l}\text { Turnover } \\
\text { (RM' billion }\end{array}$} \\
\hline & & & & & & \\
\hline 2011 & 9,074 & $7,040,309$ & & 10.49 & 92.80 & 23.09 \\
\hline 2012 & 10,087 & $7,028,715$ & & 11.71 & 100.41 & 31.10 \\
\hline 2013 & 10,914 & $7,609,204$ & & 12.81 & 107.90 & 32.97 \\
\hline 2014 & 11,871 & $7,409,547$ & & 13.47 & 116.79 & 34.95 \\
\hline 2015 & 12,769 & $7,491,191$ & & 13.81 & 123.28 & 33.56 \\
\hline 2016 & 13,428 & $7,066,222$ & & 13.99 & 130.74 & 39.66 \\
\hline 2017 & 13,899 & $6,553,597$ & & 14.35 & 139.68 & 40.24 \\
\hline $2020 \mathrm{e}$ & & & & & & 50.00 \\
\hline
\end{tabular}

Source: Malaysia Co-operative Societies Commission, (2018)

According to Table 1, there were 13,899 registered cooperatives in Malaysia with almost 7 million members and turnover amounted to RM40.24 billion at the end of 2017. Thus, it indicates about $20 \%$ of the total population of Malaysia are members of co-operatives and privileged within their social and economic benefits respectively. It also presents a positive turnover growth at an average rate of 10\% from 2011 to 2017 which indicate the capability of co-operatives to achieve the expected contribution of RM50 billion by year 2020. The involvement of the co-operative in the high-impact economy sector such as banking and financial services, housing, transportation, agriculture, as well as wholesale and retail has increased co-operative reputation in the public's confidence and perceptions on co-operative movement.

The World Co-operative Monitor: Exploring the Co-operative Economy Report 2018 has specified the rankings of Top 300 world's largest cooperative based on 2016 financial data. However, only two co-operatives from Malaysia were nominated in the Top 300 Largest Cooperative and Mutual Organisations (Turnover/GDP per capita) namely Bank Kerjasama Rakyat Malaysia Berhad and Koperasi Permodalan Felda Malaysia Berhad which held position 68 and 232, respectively. Therefore, it is important to further improve the public's confidence on co-operative movement to increase citizen participation, share capital and performance. It can be done through communication of its success, achievements, profitability and commitment to improve its social performance. According to Zaridis \& Mousiolis (2014), the success and failures of co-operatives mainly depend on the organization structure that arises from the ownership and control. Due to the absence of adequate corporate governance and lack of internal control to detect and prevent fraud, misconduct and financial scandals, abuse of power, conflicts of interest and other dishonest behaviours which eventually resulted in the collapse of co-operatives (Rohana Othman et al., 2016).

Since 1975, a significant number of co-operatives suffered mismanagement, either due to lack of expertise or professionalism, corruption, fraudulent and dishonest acts; which resulted not only in financial fiascos and collapse but also accompanied with distressing social and economic consequences. Mohamad \& Othman (2013) suggested that co-operative's image and reputation could be damaged by negative events exposed to the public through the media, thus, it would worsen the public's trust on co-operative movement in Malaysia.

\subsection{Motivation}

The financial fiascos and collapse in co-operatives in recent decades have tarnished the co-operative reputation as well as deteriorated public confidence in the co-operative movement. In order to strengthen the role of co-operatives in the national economic development, the government issued specific policies for the co-operatives in 2002, with the introduction of the National Co-operative Policy 2002-2010 (NCPI). Currently under NCPII, the co-operative sector has been targeted as the third engine of national economic development by stimulating the participation of co-operatives in the high value sector, as well as strengthening co-operatives through effective supervision and enforcement.

The implications of co-operatives' mismanagement and failures not only diminish economic and social development, 
but also accompanied by distressing effects to a large group of stakeholders such as members, the government, employees, creditors and lenders. Co-operatives in Malaysia faced issues such as absence of good governance, weak governance structure, lack of integrity, lack of managerial talent or expertise, insufficient capital in some co-operatives and poor networking (M. Mohamad, Othman, \& Mohamed, 2013). The Central Bank of Malaysia in their audit report confirmed that the weaknesses of the Malaysian co-operatives was influenced by weak financial performance, inadequate cash flow and mismanagement, lack of investigation and punishment against members who violated the law, as well as non-compliance with the co-operative principles (Bidin, 2007; Hashim \& Fawzi, 2015; M. Mohamad et al., 2013). In addition, the negative events exposed in the media to the community will damage the co-operative's image and reputation (M. Mohamad \& Othman, 2013), hence obstructing co-operative growth in Malaysia.

In the business world, Fortune Ranking has been a good reference for determining the performance and reputation of companies in the United States (Bear \& Post, 2010; Fombrun \& Shanley, 1990; Fryxell \& Jia Wang, 1994). In their effort to evaluate the performance of co-operatives, MCSC had introduced the Top 100 Co-operatives Index to recognize the performance of excellent co-operatives in Malaysia. This index has been published on the MCSC's website since its inception in 2009. According to Mayo (2011), the co-operative's performance is measured based on a set of measurement tools and framework developed by the Co-operative Appraisal Committee. Those co-operatives which are listed in the rating are believed to be involved in the high value economic sector, possess competent management and sustainable business. Supported by Mohamad \& Othman (2013), the achievements of co-operatives in the Top 100 Co-operatives will improve stakeholders' judgements on co-operative image and reputation.

The interest of corporate reputation had grown in recent years with several empirical studies examining the benefits and antecedents of corporate reputation. A good corporate reputation would be able to attract customer and good employees, increase loyalty, enhance corporate branding which may be useful to gain sustainable competitive advantage, as well as obtaining the capital (Wiedmann \& Buxel, 2005). Research on this topic have discovered several antecedents of corporate reputation such as firm performance, quality of product, customer satisfaction, media visibility, size, firm risk, age, competitive actions and corporate governance (Fombrun, 1996; Fombrun \& Shanley, 1990; Kitchen \& Laurence, 2003; Kumaran \& Thenmozhi, 2016; M. Mohamad \& Othman, 2013; Wiedmann \& Buxel, 2005). Moreover, the importance of corporate governance mechanism has been urged by academicians and regulators over past decades in affecting internal control, performance, information quality and earnings management (Al-Baidhani, 2014; Collins, LaFond, \& Ashbaugh-Skaife, 2006; Shahwan, 2015; Yadav, 2013) as well as corporate reputation (Bear \& Post, 2010; Brammer, Millington, \& Pavelin, 2009; Kumaran \& Thenmozhi, 2016; Musteen, Datta, \& Kemmerer, 2010). An effective corporate governance mechanism in the organization will protect investors, maximize shareholders value and increase confidence in the capital market. According to Yadav (2013) a sound corporate governance mechanism has reduced the likelihood of negative financial outcomes and creative accounting, eventually carried a better image and more valued in terms of reputation in the eyes of their stakeholders. The role of board of directors are relevant mechanisms in the oversight of managerial actions (Fama \& Jensen, 1983) and are able to reduce the likelihood of information asymmetries and improve firm performance, hence enhancing corporate reputation.

This study is motivated by the desire to fill the conspicuous gaps in corporate governance mechanism and reputation in the co-operative sector. Rohana Othman et al., (2016) in their exploratory study on Malaysian co-operatives explained that deterioration in the state and performance of numerous co-operatives in Malaysia had increased the awareness on co-operative's governance among the concerned public and researchers. The absence of research that investigate the potential relationship between corporate governance mechanism, specifically board characteristics and co-operative reputation in Malaysia, has created great interest for a study to be conducted on this topic. The aim of this study is to examine the potential relationship between corporate governance mechanism, specifically board characteristics and co-operative reputation in Malaysia.

\section{Literature Review}

\subsection{Co-operative Movement in Malaysia}

In Malaysia, co-operative is an organization that is registered under the Co-operative Societies Act 1993 [Act 502] with the aim of promoting socioeconomic interests among its members in accordance with the principles of co-operatives. Co-operatives society defined in the Act, as an "autonomous association of persons united voluntarily to meet their common social, economic, and cultural needs and objectives through a jointly-owned and democratically controlled enterprise" (Act 502, p.11). MCSC has established seven principles of co-operative in accordance with the International Co-operative Alliance (ICA) which include voluntary and open membership; 
democratic and member control; member economic participation; autonomy and independence; education, training and information; co-operation among co-operatives; and concern for the community. The first co-operative in Malaysia was registered in Taiping, Perak in July 1922. It was initiated by the British administrator to solve the indebtedness problem among low wage workers, including civil servants in urban areas and to protect the welfare of paddy farmers in rural areas. Since then, co-operatives have been recognised as a vehicle to raise living standards among rural and low-income people with their ability to mobilize resources between the urban and rural areas (National Co-operative Policy, 2011).

The co-operative sector plays an important role in the socioeconomic development by creating jobs and business opportunities, improving the quality of life and helping to reduce poverty in Malaysia (Mahajar \& Mohd Yunus, 2005) based on its principles. In recognizing the potential of co-operatives in terms of social and economic development, the co-operative sector was targeted as the third engine of the national economic development together with public and private sectors in Malaysia. The first National Co-operative Policy $2002-2010$ (NCP I) was launched in January 2004 to provide a conducive environment and to transform the co-operative into becoming competitive, resilient, progressive and equipped with integrity for the national development in line with Vision 2020. In relation to that, the government incorporated the Co-operative Development Department of Malaysia which was established since 1922 into the Malaysia Co-operative Societies Commission (MCSC) in 2008.

Moreover, the National Co-operative Policy 2011-2020 (NCP II) had outlined initiatives and strategic thrusts to further transform the co-operative movement in Malaysia into a competitive sector and become an active player in the national economy. The co-operatives are expected to contribute 5\% of the Gross National Product (GNP) by 2013 and 10\% GNP by 2020. In 2013, MCSC reported a substantial number of 10,914 co-operatives had registered but failed to achieve the goals of 5\% GNP set due to the low contribution from the co-operatives sector towards economic growth as compared to the public and private sectors. Thus, NCP II has been revised to strengthen the co-operatives strategic plan for the next five-year period from 2015 to 2020 in the 11th Malaysia Plan and to reset the main objective and increase the co-operatives contribution to GNP further to RM50 billion in 2020. The co-operative movement in Malaysia remains to expand in various economy sectors such as banking and financial services, construction, transportation, consumer, industrial, services, agricultural and housing. Table 2 presents the performance of co-operatives in Malaysia by industry sectors as of $31^{\text {st }}$ December 2017 which includes number of co-operatives, number of members, share capital, asset and turnover.

Table 2. Statistic of co-operatives by industry sector as at $31^{\text {st }}$ December 2017

\begin{tabular}{|c|c|c|c|c|c|}
\hline \multirow[t]{2}{*}{ Industry } & \multirow{2}{*}{$\begin{array}{l}\text { Number } \\
\text { co-operative }\end{array}$} & \multirow{2}{*}{$\begin{array}{l}\text { Number } \\
\text { members }\end{array}$} & \multirow{2}{*}{$\begin{array}{l}\text { Share Capital } \\
\text { (RM' billion) }\end{array}$} & \multirow{2}{*}{$\begin{array}{l}\text { Asset } \\
\text { (RM' billion) }\end{array}$} & \multirow{2}{*}{$\begin{array}{l}\text { Turnover } \\
\text { (RM' billion) }\end{array}$} \\
\hline & & & & & \\
\hline Credit & 587 & $1,256,259$ & 6.38 & 14.92 & 6.68 \\
\hline Construction & 249 & 95,682 & 0.03 & 0.23 & 0.06 \\
\hline Transportation & 484 & 136,418 & 0.07 & 0.34 & 0.63 \\
\hline Consumer & 5,347 & $2,314,700$ & 0.48 & 2.12 & 1.62 \\
\hline Banking & 2 & 954,426 & 3.35 & 108.30 & 26.77 \\
\hline Industrial & 344 & 18,824 & 0.01 & 0.08 & 0.03 \\
\hline Services & 3,569 & $1,023,565$ & 3.14 & 8.83 & 2.97 \\
\hline Agricultural & 3,026 & 608,735 & 0.68 & 3.86 & 1.24 \\
\hline Housing & 291 & 144,988 & 0.19 & 1.00 & 0.24 \\
\hline Total & 13,899 & $6,553,597$ & 14.35 & 139.68 & 40.24 \\
\hline
\end{tabular}

Source: Malaysia Co-operative Societies Commission, (2018)

The co-operative movement is facing numerous challenges internally and externally, which have influenced its performance. Therefore, some forms of performance measurement is essential to ensure the co-operatives' contribution to the nation's social and economic development (Mahazril'Aini, Hafizah, \& Zuraini, 2012). In an effort to evaluate the performance of co-operatives, MCSC had introduced Malaysia's Top 100 Co-operatives Index, where the performance of co-operatives is evaluated based on a standard set of measurement tools and framework developed by the Co-operative Appraisal Committee in MCSC (Mayo, 2011). MCSC has adopted standards sets in 
accordance with the Co-operative Industrial Average (CIA) ratio and aligned with criteria sets by the International Co-operative Alliance ("Top 100 Co-operatives in Malaysia," 2017). Co-operatives which are listed in the index are perceived to be involved in high value economic sector and successful, hence signalling good reputation to the members, investors and other stakeholders.

\subsection{Corporate Reputation}

Prior researchers have created various definitions regarding reputation. According to Fombrun (1996 p.72) reputation can be defined as "a perceptual representation of a company's past actions and future prospects that describe the firm's overall appeal to all its key constituents when compared to other leading rivals". He described four elements of reputation which comprises responsibility, reliability, credibility and trustworthiness. Meanwhile, Wiedmann \& Buxel (2005) defined a corporate reputation as the insights, perceptions and evaluations by relevant stakeholders with regard to the performance, products, services, persons and organizations, as well as confidence and respect for the company. Barnett, Jermier, \& Lafferty (2006 p.34) have done exploratory research to study the corporate reputation definitional landscape. They defined corporate reputation as "Observers' collective judgments of a corporation based on assessments of the financial, social, and environmental impacts attributed to the corporation over time".

Like companies, the co-operatives reputation is also important in managing the business and without a good reputation it is very difficult for co-operatives to sustain or make progress in the competitive market. Despite being intangible, the researchers suggested that reputation may be influenced by various factors such as ethical conduct, firm performance, management, leadership, employees, corporate social responsibility, quality of product, customer satisfaction, media visibility, size, firm risk, age, competitive actions and corporate governance (Fombrun, 1996; Fombrun \& Shanley, 1990; Kitchen \& Laurence, 2003; Kumaran \& Thenmozhi, 2016; M. Mohamad \& Othman, 2013; Wiedmann \& Buxel, 2005).

In the co-operatives context, cumulative stakeholders' perception lead to superior reputation that is beneficial to the co-operatives. Mohamad \& Othman (2013) in their study on Malaysian co-operatives suggested that reputation of co-operatives shall be enhanced by disseminating the latest information on ethical and governance practices, co-operative activities and financial position as well as its annual report on its website. On the other hand, co-operative's image and reputation will be damaged by negative news exposed to the public. In other words, the excellence of co-operatives is impossible to maintain without internal organization support and monitoring; hence, corporate governance plays an important role as the mechanism to improve the reputation of co-operatives.

\subsection{The Underpinning Theory - Resource Based View Theory (RBVT)}

Reputation is an intangible resource that is constructed from the stakeholder's perceptions and represents the public's cumulative judgement on the firm over time. To further explain the reputation concept, this study adopted resource based view theory (RBVT) that viewed reputation as a strategic resource or a key intangible resource in firms that represent important basis of sustainable competitive advantages (Barney, 1991; Wernerfelt, 1984). Substantial information has been paid towards the Resource Based View Theory (RBVT) to determine variances regarding internal factors in firm performance for the last 30 years. The growth of the resource-based approach has shifted focus of strategic management researchers regarding the sources of sustainable competitive advantage from the industry to firm specific factors which emphasized on internal resources in the firm.

Initiated by Wernerfelt (1984), RBVT emphasized on the internal factors or firm resources that were largely affecting the firms' success, rather than the industry factor. He suggested that acquisition of heterogeneous and idiosyncratic firm resources is essential to superior performance and beneficial to obtain sustainable competitive advantage in the capital market. He further explained the firm possessed bulk of resources and reasoned that "resources and products are two sides of the same coin" (Wernerfelt, 1984, p. 171). Fombrun (1996) supported this statement and explained that corporate reputation is used by outsiders to evaluate the quality of products and to determine the growth perspective. Previous empirical studies highlighted the ability of firms to control resources that potentially provide sustainable competitive advantage (Barney, 1991; Wernerfelt, 1984) which consequently leads to better performance (Barney, 2001; Bridoux, 2004; Orlando, 2000) and firm success (Galbreath, 2005).

There are various types of resources categorised by previous researchers. Wernerfelt (1984) defined resources as physical assets, intangible assets, and organizational capabilities owned and controlled by the firm. Meanwhile, according to Barney (1991), resources are classified into physical capital resources, human capital resources and organizational capital resources. Wernerfelt (1984) stated that companies acquire competitive advantage through tangible and intangible resources, while Galbreath (2005) summarized that resources can be defined as assets and capabilities. Assets consist of tangible assets such as financial and physical assets; and intangible assets such as 
intellectual property, organizational and reputational assets that are owned or controlled by the firm. Meanwhile, capabilities refer to intangible skills, experiences and knowledge exercised through organizational activities.

Corporate reputation is seen as an intangibles resource in nature that can generate value-added and exhibit rarity, since not all companies have a good reputation. It is also difficult to imitate and not easily substituted with other rivals in the market. As such, reputation conforms the characteristics of intangibles resources that can be a source of sustainable competitive advantage (Barney, 1991). He suggested that competitive advantage can only be generated and sustained by firm resources that are valuable (V), rare (R), inimitable (I) and non-substitutable $(\mathrm{N})$, which is the so-called VRIN criteria framework. Therefore, in considering the idiosyncratic and heterogenous in firm resources as fundamental perspective in explaining why some firms are superior to others, the RBV posits such a position. Prior researchers found that intangible resources are the most important resources to firm success due to heterogeneity and difficulty to duplicate (Barney, 1991). While Galbreath (2005) supported that further findings emphasized that capabilities significantly contributed to firm success compared to intangibles and tangible assets. He suggested that firms dynamically seek to construct knowledge based either in human capital or systematic processes to enable the development, management and transference of knowledge across the organization. In this context, it is realistic both in theory and practical, to examine the relationship between firm resources in terms of board capabilities and co-operative reputation due to their successful performance.

\subsection{Board Characteristics and Co-operative Reputation}

The role of board of directors in organizations is vital to oversight managerial decisions of firms, as well as to protect shareholders and investors. Board of directors are relevant mechanisms in the organization to oversee the managerial actions (Fama \& Jensen, 1983) and protect shareholders interest. Board of directors are able to reduce the likelihood of information asymmetries and improve firm performance, hence enhancing corporate reputation. In the view of the RBV approach, idiosyncratic and heterogenous firm resources from diversified boards can enhance sustained competitive advantage (Barney, 1991; Bridoux, 2004), firm performance (Rohana Othman et al., 2015) and reputation (Fombrun \& Shanley, 1990). There has been little evidence of corporate governance literature in the co-operative society's environment (Shamsuddin, 2015). Like corporate boards, co-operative boards play an essential role in linking the manager's actions to the members and investors interests. Numerous empirical researchers are concerned with the impact of board characteristics on financial performance, but few focuses on the impact toward corporate reputation. However, there are extant empirical studies that found inter relationships between firm performance and reputation (Boyd, Bergh, \& Ketchen, 2010; Fombrun \& Shanley, 1990; García-Meca \& Palacio, 2018; Kitchen \& Laurence, 2003; Wiedmann \& Buxel, 2005). Corporate reputation reflects the impression of key stakeholders about the firm, as well as the firm's performance where they rely on other organizational attributes to judge the firm's reputational value. Hence, it can be stated that board characteristics may influence corporate reputation due to their successful performance. The upgrading stakeholders' perceptions about a firms' performance will or can lead to an enhancement in corporate reputation, and this would bring significant benefits and sustained competitive advantages to the firm.

Bravo, Abad, \& Briones (2015) found the relationship between corporate governance and reputation which see the firm as serving various stakeholders that evaluate the corporate effectiveness based on various information about firms' activities, achievements and prospects. Additionally, Kitchen \& Laurence (2003) in their empirical study on corporate reputation with executives from eight countries found a significant relationship between CEO's reputation and corporate reputation. They found that the CEO's reputation helped in sustaining their business either national, international or globally. Otherwise, the CEO's bad reputation will demolish business growth and corporate reputation to sustain businesses in the competitive market. A diverse board is a well-proportioned board where the directors come from different backgrounds and professional fields which will create synergy to help these boards carry out their roles and duties (Carpenter \& Westphal, 2001). In posit RBV approach which was built on the assumption that firm strategic resources are heterogeneously distributed and linked with sustained competitive advantages, this study examines the relationship between firm resources, specifically board characteristics with corporate reputation.

According to Bear \& Post (2010) who studied corporate reputation in 689 companies in the United States, they found that gender composition in the board has a significant positive relationship with the strength of fortune rating. It is also supported by Duc \& Thuy (2013) who found that female directors have a positive impact to firm performance in the 77 listed firms in Vietnam. They explained the benefits of having female composition in board, where female directors may hold greater understanding on particular market conditions compared to male directors, which may carry more creativity, inspiration and quality in the decision-making processes. On the other hand, ethnic diversity will provide a wider range of ideas, knowledge and experience from broad information resources of cultural 
background among board members. High level of cultural heterogeneity in management would allow shared information among the multiracial group of the boards to gain sustainable competitive advantage.

Moreover, diversity in the boardroom continues to be the interest of many researchers but the focus is limited on the diversity of ages. People from different age groups bring different perspectives and life experiences to the work culture by being on the board of directors. Previous studies had revealed that there are very limited directors aged below 40; where mostly directors were in their mid-sixties serving on the board. There are also a significant number of directors in their seventies and eighties (Barrett, 2017). She further explained that there is little distribution in the average age of directors between different S\&P 500 company boards with the average age of all boards being around 62.4 years old. Cambrea et al., (2017) investigated the relationship between board diversity with the firm's performance in 78 listed companies operating in the fashion and luxury industries, over the five-year period from 2011 to 2015. They found that TMTs with more female directors, international experience, and educational diversity are positively associated with superior firm performance. However, directors with greater ages, by means of national and professionalism diversity will not significantly influence firm performance.

In view of the RBV approach, heterogeneity in educational backgrounds may improve problem-solving and strategic decision-making capabilities, especially in the dynamic and competitive industry environments. A formal education reflects an individual's competencies and capabilities well equipped with management knowledge such as finance, accounting, marketing, information systems, legal issues and other related areas to the decision making (Cambrea et al., 2017). The shifting nature of the co-operatives required the directors' capability to possess recent knowledge and intellectual abilities to cope in the rapid and competitive economic development. Thus, higher level of educational qualification such as Master and Doctor of Philosophy $(\mathrm{PhD})$ will function as a strategic resource believed to possess a mix of competencies and capabilities that will result in higher quality decision making, enhance firm performance and eventually firm reputation (Adnan et al., 2016; Carpenter, Geletkanycz, \& Sanders, 2004; Darmadi, 2013).

\section{Hypotheses Development}

\subsection{Board Size}

Board size has been widely used as a metric by governance rating agencies in evaluating corporate board where firms with smaller boards were regularly viewed unfavourable by such agencies (Musteen et al., 2010). Based on RBV's point of view, it can be posited that firms with larger boards are likely to acquire a wider range of knowledge, skills, and capabilities derived from heterogeneous board members who will eventually enhance sustained competitive advantage, performance and success of the firms (Barney, 1991; Bridoux, 2004; Galbreath, 2005; García-Meca \& Palacio, 2018; Rohana Othman et al., 2015).

Collins, LaFond, \& Ashbaugh-Skaife (2006) examined the relation between the composition of the overall board and of various committees and firm performance and suggested the number of board members is six to fifteen. It is perceived that a greater or wider board size would lead to more opportunities for networking, bring more experience, knowledge and skill in order to improve the firm's performance. According to Musteen et al. (2010), firms with larger board member in USA exhibited a better reputation compared to those with smaller boards. Their findings was supported by Abdulazeez DA, Ndibe L, \& Mercy AM (2016) who found significant positive relationship between board size and financial performance, which indicate that the increase in board size will increase the performance of the bank. Despite the evidenced advantage of having a larger number of board members, the bigger size will consequently be more challenging with complicated coordination and processes. Jensen (1993) suggested the appropriate board size is eight, as finding larger board sizes have more difficulty in reaching the quorum. He explained that when the board size grows bigger, they lose their effectiveness. Accordingly, the following hypothesis is proposed:

\section{H1: Board size is positively associated with co-operative reputation}

\subsection{Ethnic Diversity}

According to Hambrick, Cho, \& Chen (1996) ethnic diversity broadens idea, experience and knowledge through the wide range of information resources from different cultural backgrounds among the board members. An organization with a high level of cultural heterogeneity in management is able to share ideas and better decision-making capabilities based on the various thoughts. The RBV theory highlighted that idiosyncratic and heterogeneous firm resources from diversified boards may enhance sustained competitive advantage (Barney, 1991; Bridoux, 2004), together with the firms' performance (Orlando, 2000; Rohana Othman et al., 2015) and firms' success (Galbreath, 2005). Thus, sharing cultural characteristics will enhance the management's performance and reputation through a mutual consensus among the multi-racial members of the board. According to Fombrun \& Shanley (1990) a firm's superior performance would enhance its corporate reputation. 
Orlando (2000) investigated in his study whether racial or ethnic diversity interacted with business strategy in determining firm performance in posits of the RBV approach. The results revealed that ethnic, racial and cultural background does add value and contributes to firms' competitive advantage. In addition, Shukeri et al. (2012) have found significant positive relationship between ethnic diversity with ROE which is consistent with Abdullah \& Ku Ismail (2013), where they demonstrated that a multi-racial board had positively influenced firm performance among public listed companies in Malaysia. Thus, the following hypothesis is developed to show the relationship in this study.

\section{H2: The proportion of ethnic diversity on the board is positively associated with co-operative reputation.}

\subsection{Gender Diversity}

Huang et al. (2015) stated the boards were highly dominated by male directors among Malaysian co-operatives than female. They found insignificant gender diversity effect towards co-operatives performance. However, their study was only based on 34 co-operatives from 2008 to 2012, where a large sample might result in different findings. Duc \& Thuy (2013) and Bear \& Post (2010) revealed positive relationship between female directors with financial performance and reputation. They specified that female directors may better understand particular market conditions than male directors', which brings more creativity and quality to board decision making. In relation to RBV's theory, the heterogeneous resources based on gender diversity can improve the better public's image and firm's performance. Bear \& Post (2010) suggested that higher gender diversity on the board may represent better firms' image to the public and consequently improve firms' reputation. Moreover, the involvement of women in the board may become an inspiring model and positively impact the career development of women in lower positions. These findings are not supported by other researchers who found negative effects between gender and firm performance (Abdullah \& Ku Ismail, 2013; Marimuthu \& Kolandaisamy, 2009). Accordingly, further study on co-operatives leads to the following hypothesis.

\section{H3: The proportion of female directors on the board is positively associated with co-operative reputation.}

\subsection{Board Age}

Extant empirical researchers suggested that people of similar ages tend to perceive situations through analogous lenses, reflecting shared experiences and information (Abdullah \& Ku Ismail, 2013). This may lead to conformism in strategic decision-making as well as biased to particular age segment of the market. By appointing directors from diversified age bands, the board is able to obtain valuable information from directors who better understand the stakeholders' needs and sensitivities in their age band. Hence, as per the RBV theory, diversified ages among members of the board will be useful in generating creative ideas or problem-solving to overcome barriers by leveraging on a wider range of knowledge, skills, and abilities derived from heterogeneous board members; who would lead the firms towards better performances and eventually their success.

Abdullah \& Ku Ismail (2013) reported that board members of Malaysian firms are dominated by directors with an average age of between 55 to 60 years old. In the meantime, Barrett (2017) examined age diversity within the boards of the US companies in the S\&P 500 found that $80 \%$ of companies were dominated by directors aged between 60 to 69 years with an average age of 62.4 on the board. While the older directors are more experienced, younger directors are needed as they are expected to bring new ideas and perspectives to the board. Interestingly, Duc \& Thuy (2013)'s study on Vietnamese firms identified the average age of directors was 48.4 years old and revealed a positive relationship between board age and firm performance. They evidenced that board members with a greater age average embraced more working experience compared to a younger age average, in which this experience contributed to the better performance of a firm. According to Fombrun \& Shanley (1990) firm performance influenced better corporate representation and reputation. Therefore, the following hypothesis is proposed:

\section{H4: Board age is positively associated with co-operative reputation.}

\subsection{Education Diversity}

A formal education reflects an individual's cognitive capabilities and diversity where the educational background is generally related to a variety of perspectives and skill sets of the top management team (Cambrea et al., 2017). A more diverse and expert board may be more innovative, creative and capable of higher quality decision making. Therefore, based on the RBV approach, heterogeneity or the diversity in educational backgrounds may enhance problem solving and strategic decision-making capabilities in organizations, especially in the dynamic and competitive industrial environments.

Numerous studies have investigated the positive relationship between educational diversity with a high number of organisational outcomes, such as strategy, innovation and performance; where they found a positive relationship 
between top management educational diversity and firm performance (Adnan et al., 2016; Carpenter et al., 2004; Darmadi, 2013; Duc \& Thuy, 2013). For instance, Cambrea et al. (2017) found a significant positive effect between greater diversified executives with high educational background with firms' performance. According to Fombrun \& Shanley (1990) firms' performance influenced superior corporate reputation. Hence, the following hypothesis is proposed in this study:

\section{H5: The proportion of education diversity on the board is positively associated with co-operative reputation}

\subsection{Theoretical Framework}

Boards of directors are responsible for the governance of their organization. In addition, the board of directors is crucial for strategic decision making within a firm, and it is responsible for setting objectives, monitoring and controlling the firm's activities (Fama \& Jensen, 1983). According to the Resource-Based View (RBV) approach, idiosyncratic and heterogenous firm resources such as diversified boards can enhance sustained competitive advantage (Barney, 1991; Bridoux, 2004), firms' performance (Orlando, 2000; Rohana Othman et al., 2015) and firms' success (Galbreath, 2005).

Therefore, the relationship between corporate governance mechanism, specifically board characteristics and co-operative reputation is examined by employing RBVT (Barney, 1991) in this study. The connection between board and corporate reputation is supported with empirical study by Fombrun \& Shanley (1990) who found firms' performance significantly enhanced corporate reputation. Figure 1 illustrates the theoretical framework that contributes to the development of research hypotheses.

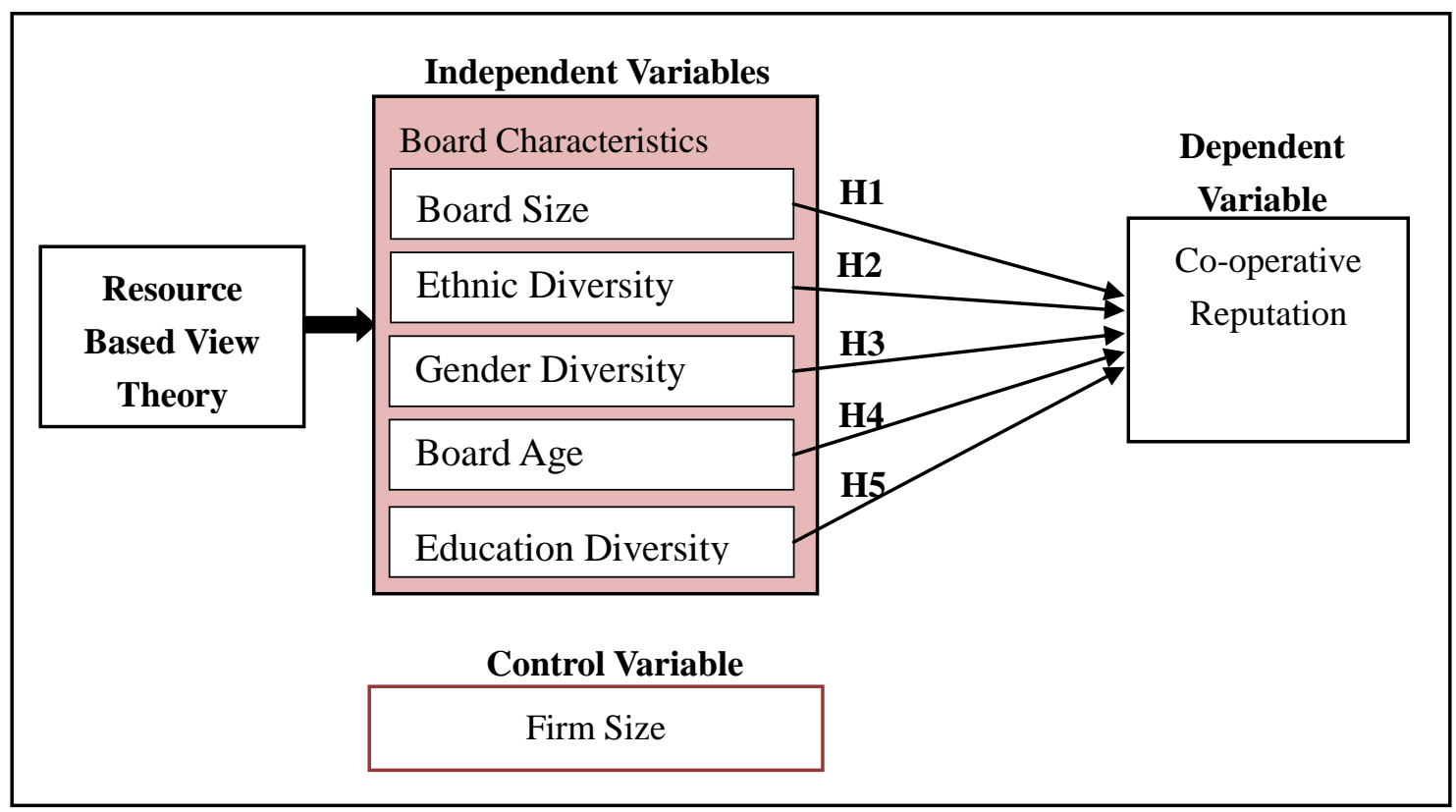

Figure 1. Theoretical framework of the relationship between board characteristics and co-operative reputation in Malaysia

Variables that are associated with this study are board of directors' characteristics such as board size, ethnic diversity, gender diversity, board age and education diversity which are considered as influencing factors to enhance the co-operatives reputation to their members and stakeholders. An important component of financial performance and reputation is firm size; thus, this study will be biased if it failed to control the firm size heterogeneity (Brammer et al., 2009; Fombrun \& Shanley, 1990; Musteen et al., 2010). Therefore, co-operative's size will be used as control variables to examine co-operative reputation in this study.

\section{Research Methodology}

This study examined the relationship between corporate governance mechanism and co-operative reputation which is based on the 100 co-operatives listed in the rating for 2015 until 2017. The sample was drawn from the Top 100 Co-operatives Index published in the Malaysia Co-operative Societies Commission's (MCSC) website; which 
employs a similar assessment to construct the Fortune index, a commonly used measurement for US firms' reputation (Fombrun \& Shanley, 1990; Fryxell \& Jia Wang, 1994). This study employs the cross-sectional method for the period from September until November 2018. Samples are selected using non-probability, purposive sampling on the total population of co-operative reputation in Malaysia. Based on the study observation, there were 64 co-operatives listed in the Top100 Co-operatives Index for three consecutive years from 2015 until 2017. However, the banking sector which was represented by Bank Kerjasama Rakyat Malaysia Berhad and Koperasi Bank Persatuan Malaysia Berhad, are excluded in this study due to different types of disclosure requirements and regulations. It is consistent with extant empirical studies that suggests heterogeneous characteristics need to be controlled by excluding the sample from the financial industry (Adnan et al., 2016; Marimuthu \& Kolandaisamy, 2009). Meanwhile, Angkatan Koperasi Kebangsaaan Malaysia (ANGKASA) is also excluded from the service sector due to its role as the apex of cooperatives for the Malaysian co-operative movement, where there is no board of directors in ANGKASA but is led by the National Administrative Committee.

\subsection{Data Collection Method}

Data for this study were mainly obtained from the Malaysian Co-operative Societies Commission (MCSC) website and INFOKOP system that provides both financial and non-financial data. The data collection for reputation ranking from 2015 to 2017 was obtained from the Top 100 Co-operatives Index which has been published on the MCSC's website. However, to be consistent with extant empirical research of corporate reputation, all the explanatory variables are lagged by a year (Bravo et al., 2015; Fombrun \& Shanley, 1990; Musteen et al., 2010), which the data of board characteristics and relevant financial data was collected from INFOKOP System covering a three-year period from 2014 to 2016, as well as the co-operatives' website when necessary. An important component of financial performance is firm size; thus, this study will be biased if it failed to control the firm size heterogeneity (Brammer et al., 2009; Fombrun \& Shanley, 1990; Musteen et al., 2010). Therefore, co-operative's size will be used as control variables to co-operative reputation. The list of the data is shown in Table 3 . The secondary method is selected because it is more convenient, and data was available as well as the nature of research design which required past and documented facts as basis for the corporate reputation evaluation.

Table 3. Extracted variables from INFOKOP system

\begin{tabular}{lll}
\hline No. & Variable & Abbreviation \\
\hline 1. & Independent: Board Size & BSIZE \\
2. & Independent: Ethnic Diversity & BETH \\
3. & Independent: Gender Diversity & BGEN \\
4. & Independent: Board Age & BAGE \\
5. & Independent: Education Diversity & BEDU \\
6. & Control: Co-operative Size & SIZE \\
\hline
\end{tabular}

\subsection{Statistical Data Analyses}

The Statistical Package for Social Science (SPSS) software version 23 is used to analyse the data collected from this study. SPSS programme is useful in analysing and examining the hypotheses as formulated in the earlier section. Therefore, the relationships that are analysed can be expressed using the following equation.

The model used is as follows:

REPUit $=\beta 0+\beta 1 \mathrm{BSIZE} i t+\beta 2 \mathrm{BETH} i t+\beta 3 \mathrm{BGEN} i t+\beta 4 \mathrm{BAGE} i t+$

$\beta 5 \mathrm{BEDU} i t+\beta 6 \mathrm{SIZE} i t+\mathcal{E}$

Where:

$\beta 0=$ Constant coefficient (intercept)

$\beta 1$ to $\beta 6=$ Coefficients of independent and control variables (explanatory)

REPU = Co-operative reputation, BSIZE $=$ Board size, BETH $=$ Ethnic diversity

BGEN = Gender diversity, $\mathrm{BAGE}=$ Board Age, $\mathrm{BEDU}=$ Education diversity

SIZE = Co-operative size on $\log$ of total assets, $\mathcal{E}=$ Residual component of model

In the above equation, ' $i$ ' denotes the co-operative and ' $t$ " the examined time period. 


\section{Results}

\subsection{Descriptive Statistics}

There were 183 co-operatives sample observed in this study. Reputation score (REPU) is a relative measure based on the average ranking position in the Top100 index, which assigned 100 points for the $1^{\text {st }}$ position and 1 point is assigned for the lowest rank at the $100^{\text {th }}$ position. Based on the table, it indicates the average means score of the co-operative reputation was 55.137 and the standard deviation of 28.023. This shows that the listed co-operatives in Top 100 Co-operatives Index for three consecutive years have the average (median) score of 57 with minimum value of 2 and maximum value of 100. Findings of descriptive statistics for all variables (including control variable) is presented in Table 4.

Table 4. Descriptive statistics of variables

\begin{tabular}{llllll}
\hline Variables & Mean & Median & Minimum & Maximum & Std. Deviation \\
\hline REPU & 55.137 & 57.00 & 2.00 & 100.00 & 28.023 \\
BSIZE & 11.57 & 12.00 & 6.00 & 15.00 & 2.149 \\
BETH $(\%)$ & 3.432 & 0.00 & 0.00 & 40.00 & 9.343 \\
BGEN $(\%)$ & 8.787 & 8.333 & 0.00 & 44.44 & 10.415 \\
BAGE & 57.349 & 57.00 & 36.17 & 75.27 & 6.466 \\
BEDU $(\%)$ & 7.837 & 0.00 & 0.00 & 66.67 & 13.538 \\
SIZE & 7.608 & 7.591 & 6.18 & 9.70 & 0.788 \\
Valid N $=183$ & & & & & \\
\hline
\end{tabular}

For the independent variables of board size (BSIZE), the value of mean, minimum, maximum and standard deviation are $11.56,6,15$ and 2.149 respectively. Table 4 indicates that the board size in co-operatives range from 6 to 15 with an average median of 12 over the three-year period of the sample. The result is consistent with the findings of Rohana Othman et al.(2016) that co-operatives in Malaysia range between 6 to 15 members on the board in accordance with Section 42 of Act 502.

For ethnic diversity (BETH), the results indicate a minimum proportion of $0 \%$ and maximum of $40 \%$ of total directors who are multiracial. The average means score and standard deviation and for ethnic diversity is 3.43 and 9.343 respectively. It represents on average mean of only $3.43 \%$ and average median $0 \%$ of multiracial directors on the board. 156 out of 183 total observations are zero diversified. This ensemble with the nature of co-operatives that was established based on mutual needs and societies.

Meanwhile, the average mean score and standard deviation of gender diversity (BGEN) on Malaysian co-operatives board are $8.79 \%$ and 10.415 respectively. The gender diversity in co-operatives range from zero to 44.44 which indicates the maximum participation of $44.44 \%$ female directors on the board. The results is consistent with Huang et al., (2015) that found the board of Malaysian co-operatives is highly dominated by males with a maximum of $30 \%$ for gender diversification.

In terms of board age (BAGE), the value of mean and standard of deviation are 57.349 and 6.466 respectively. The study finds that more than 50\% of co-operatives fall within the 50-59 age band, 33\% within 60-69 age band with the average age of board at 57 years old which is lower than extant literature; Barrett (2017) found the average age of board members in the S\&P 500 US companies was at 62.4. This finding is consistent with the evidence found on Malaysian boards (Abdullah \& Ku Ismail, 2013). The minimum average of directors' age in the co-operatives is 36.17 with the maximum of 75.27 years old.

With respect to education diversity (BEDU), the results indicate an average mean score, minimum, maximum and standard deviation of 7.837, 0, 66.67 and 13.54 respectively. It represents on average mean of only $7.837 \%$ directors on the board who held higher qualifications such as Master and $\mathrm{PhD}$ with range proportion 0 to $66.67 \%$. However, 115 out of 183 the observations are zero education diversified, where all board of directors from the respective co-operatives not hold higher educational qualification such as Master and $\mathrm{PhD}$.

In addition, the co-operative size (SIZE) is used as the control variable which is measured by the natural logarithm of each co-operative's total assets. The results show the average, standard deviation, minimum and maximum value of co-operative size is $7.608,0.788,6.18$ and 9.7 respectively. This indicates the average size of co-operatives 7.608 with the smallest co-operatives of 6.18 and the biggest co-operatives size with 9.7 of natural logarithm of total assets. 


\subsection{Correlation Coefficient Results}

Table 5 presents the multicollinearity test with the tolerance level and variance inflation factors (VIF).

Table 5. Multicollinearity Test tolerance and VIF

\begin{tabular}{lll}
\hline Variables & Tolerance & VIF \\
\hline BSIZE & .890 & 1.124 \\
BETH & .915 & 1.092 \\
BGEN & .841 & 1.189 \\
BAGE & .881 & 1.135 \\
BEDU & .734 & 1.362 \\
SIZE & .755 & 1.325 \\
\hline
\end{tabular}

The results in Table 5 indicates that the tolerance level for all variables is more than 0.1 and the variance inflation factors (VIF) is less than 5, hence no severe collinearity exists. This is supported with prior empirical studies (Cambrea et al., 2017; Shamsuddin, Ismail, Mahmood, \& Yusoff, 2017) that stated tolerance below 0.1 and VIF more than 10 is a serious problem.

Table 6 presents the Pearson correlation analysis for the dependent, independent and control variables. However, none of the variables exceeded 0.9 . The highest correlation is -0.738 , between the dependent and control variables which are reputation and co-operative size. Accordingly, this result indicates that multicollinearity is not a serious problem and will not threaten the multiple regression results in this study. Based on the results of tolerance, VIF and correlation, multicollinearity is not an issue in this study.

Furthermore, several board characteristics such as education diversity, co-operative size and board size have shown significant at the $1 \%$ and 5\% level respectively which means it significantly has relationship to influence the co-operative reputation. Other than that, the results also show significant correlation between ethnic and gender diversity, gender and board age as well as board size and board age at the $1 \%$ and $5 \%$ level. The results of education diversity indicate that the selection of high educational board will be significantly influenced by all variables except ethnic diversity. It also reveals little negative association $(r=-0.202)$ that higher educational board is influenced by younger directors as they are expected to bring new ideas and perspectives to the board. These results indicate the importance of higher educational background that effectively affected other board characteristics which also imply the individual's cognitive ability and competencies offers competitive advantages in strategic decision-making capabilities on the board (Darmadi, 2013).

Table 6. Pearson Correlation Analysis among all variables

\begin{tabular}{llllllll}
\hline Variables & REPU & BSIZE & BETH & BGEN & BAGE & BEDU & SIZE \\
\hline REPU & 1.000 & & & & & & \\
& & & & & & \\
\hline BSIZE & $.180^{*}$ & 1.000 & & & & \\
& .015 & & & & & & \\
\hline BETH & .068 & .092 & 1.000 & & & & \\
& .361 & .218 & & & & \\
\hline BGEN & .032 & -.098 & $.262^{* *}$ & 1.000 & & \\
& .666 & .185 & .000 & & & \\
\hline BAGE & -.072 & $.160^{* *}$ & -.021 & $-.239^{* *}$ & 1.000 & & \\
& .330 & .030 & .780 & .001 & & \\
\hline BEDU & $.435^{* * *}$ & $.153^{* *}$ & .046 & $.193^{* *}$ & $-.202^{* *}$ & 1.000 & \\
& .000 & .039 & .535 & .009 & .006 & & \\
\hline SIZE & $.738^{* *}$ & $.218^{* *}$ & .042 & .031 & -.134 & $.463^{* *}$ & 1.000 \\
& .000 & .003 & .568 & .674 & .070 & .000 & \\
\hline
\end{tabular}

* Correlation is significant at the 0.05 level (2-tailed).

** Correlation is significant at the 0.01 level (2-tailed). 
Similarly, the co-operative size will be affecting co-operative reputation and the selection of board in terms of board size and educational background at $1 \%$ significant level. According to Hinkle et al.(1998), correlation coefficient between co-operative size and REPU ( $\mathrm{r}=0.738)$ is highly positive correlated, while BSIZE $(\mathrm{r}=0.218)$ and BEDU $(\mathrm{r}=0.463)$ has little and low positive correlation respectively. Thus, the results indicate that larger size of co-operative is highly positive correlated with reputation and tend to appoint greater size of board and higher educational board members. This is consistent with previous studies that suggested firm size as control variables in examining the relationship between board of directors and reputation (Brammer et al., 2009; Fombrun \& Shanley, 1990; Musteen et al., 2010).

\subsection{Multiple Regression Results}

As a predictive analysis, the multiple regression analysis is used to explain the causal relationship (Pallant, 2007; Tabachnick \& Fidell, 2007) between co-operative reputation and number of independent variables which is board characteristics; as well as co-operative size as a control variable. Table 7 shows the multiple linear regression model summary and overall fit statistics.

Table 7. Multiple Linear Regression results

\begin{tabular}{|c|c|c|c|c|c|}
\hline$\overline{\mathrm{R}^{2}(\%)}$ & & 0.559 & & & \\
\hline Adjusted $\mathrm{R}^{2}(\%)$ & & 0.544 & & & \\
\hline F-value & & 37.131 & & & \\
\hline Sig. & & 0.000 & & & \\
\hline $\mathrm{N}$ & & 183 & & & \\
\hline Variable Labels & $\begin{array}{l}\text { Expected } \\
\text { Sign }\end{array}$ & $\begin{array}{l}\text { Observed } \\
\text { Sign }\end{array}$ & Beta Coefficient & $t$ & Sig. \\
\hline$\overline{\text { Constant }}$ & & & -142.460 & -6.768 & $0.000 * *$ \\
\hline BSIZE & + & - & -0.003 & -0.004 & 0.997 \\
\hline BETH & + & + & 0.113 & 0.717 & 0.474 \\
\hline BGEN & + & - & -0.037 & -0.251 & 0.802 \\
\hline BAGE & + & + & 0.185 & 0.801 & 0.424 \\
\hline BEDU & + & + & 0.265 & 2.190 & $0.030^{*}$ \\
\hline SIZE & + & + & 24.299 & 11.852 & $0.000 * *$ \\
\hline
\end{tabular}

* Correlation is significant at the 0.05 level (2-tailed).

** Correlation is significant at the 0.01 level (2-tailed).

From the R-squared $\left(\mathrm{R}^{2)}\right)$ result, it indicates that $55.9 \%$ of the variation in co-operative reputation (REPU) is explained by the variation in board size (BSIZE), ethnic diversity (BETH), gender diversity (BGEN), board age (BAGE), education diversity (BEDU); and co-operative size on log of total assets (SIZE). The Adjusted $\mathrm{R}^{2}$ is a modified version of $\mathrm{R}^{2}$ that compares the explanatory power of regression model which contains different numbers of predictors. While taking into consideration the sample size and number of independent variables, similarly from the Adjusted $\mathrm{R}^{2}$, it indicates that $54.4 \%$ of the variation in co-operative reputation is explained by the variation in explanatory variables in this model. When the result of Adjusted $\mathrm{R}^{2}$ is decreases as compared to $\mathrm{R}^{2}$, it indicates that a predictor improved the model by less than expected by chance.

On the other hand, F-test is used for overall significance of the model and it shows if there is a linear relationship between all of the independent variable considered together with dependent variable. F-test has the null hypothesis that there is no linear relationship between the variables (in other words $\mathrm{R}^{2}=0$ ). When the F-test is highly significant, it indicates that there is a linear relationship between the variables in this model. The result from the regression model indicates that the Adjusted $\mathrm{R}^{2}=0.544$, at $5 \%$ significant level and degrees of freedom $(6,176)$, F-critical value $=2.15$ which is less than F-statistic $=37.131$. Since $\mathrm{F}$ test statistic is in the rejection region ( $\mathrm{p}$-value $<0.001$ less than 0.05 ) at $5 \%$ significance level, therefore null hypothesis is rejected.

Table 7 indicates regression coefficient $\beta 0$ which is the intercept is significant where $\mathrm{p}$-value $<0.001<0.05$, which estimate the average value of dependent variable when explanatory variables is zero. $\beta 0=-142.46$, meaning that co-operative reputation worsens at 142.46 points when board characteristics and size of co-operatives do not exist. It 
is also proven as BEDU $\mathrm{p}$-value $=0.03$ less than 0.05 indicates that there is evidence that education diversity affects co-operative reputation at the $5 \%$ significance level. Other than that, SIZE p-value $<0.001$ less than 0.05 represents that co-operative size on log of total assets significantly affects the co-operative reputation. Based on $\beta 5$ (BEDU) = 0.26 and $\beta 6$ (SIZE) $=24.299$, it indicates that education diversity on the board and co-operative size has a significant positive relationship with co-operative reputation as predicted earlier. In addition, all the explanatory variables or predictors have positive relationship with co-operative reputation as expected except for BSIZE and BGEN. Even the $\mathrm{p}$-value is not significant, $\beta 1$ (BSIZE) $=-0.003$ and $\beta 3(\mathrm{BGEN})=-0.037$, indicate that board size and gender diversity have negative relationship with co-operative reputation.

Again, based on Table 7, co-operative size on log of total assets has the highest impact and board size has the lowest impact to co-operative reputation with results of $\beta 6$ (SIZE) $=24.299$ and $\beta 1$ (BSIZE) $=-0.003$ respectively. In summary, the estimated value of multiple regression equation for this model is derived as follows:

REPU $=-142.46-0.003$ (BSIZE) $+0.113($ BETH) -0.037 (BGEN) +0.185 (BAGE)

$$
+0.265(\mathrm{BEDU})+24.299(\mathrm{SIZE})+\varepsilon
$$

\section{Discussions}

The objective in this study is to examine the relationship between board characteristics and co-operative reputation in Malaysia. There are five hypotheses tested in this study, hence further discussion for each hypothesis will continue based on the results of statistical analyses stated below.

\subsection{Board Size}

Numerous empirical studies in recent decades have evidenced the influences of board size to companies performance (Abdulazeez DA et al., 2016; Collins et al., 2006; Duc \& Thuy, 2013; Fama \& Jensen, 1983; Lipton \& Lorsch, 1992; Shukeri et al., 2012) and corporate reputation among the companies in Malaysia and other countries (Musteen et al., 2010). Subsequently, it creates a desire to test these findings in co-operatives context, which lead to the first hypothesis (H1) - board size is positively associated with co-operative reputation (H1).

From Table 7, the coefficient finding $\beta 1$ (BSIZE) $=-0.003$ in regression analysis, reveals a negative relationship that smaller size of board members will enhance co-operatives reputation. The board members in co-operatives range between 6 to 15 directors in accordance with Section 42 of Act 502, with an average of 12 directors which is higher than the recommended size in extant empirical studies. Jensen (1993) suggested the appropriate board size is eight, reasoning that larger board sizes have more difficulty reaching the quorum and tend to lose their effectiveness. However, the regression results indicate that the number of board members (BSIZE) in the co-operative shows no significant association with the reputation ( $\mathrm{p}$-value $=0.997$ more than 0.05 ). It can be best explained that the increasing or decreasing of board size would not give significant effect to co-operative reputation.

The result contradicts with previous researchers (Abdulazeez DA et al., 2016; Duc \& Thuy, 2013; Musteen et al., 2010; Shukeri et al., 2012) but consistent with the result found by Rohana Othman et al. (2016), who suggested that the board does not significantly affect the performance of the co-operative organizations. It had also become more challenging to appoint appropriate board members in the co-operatives where most of the board members are volunteers. Kasmuri (2015) stated that a huge number of co-operatives are still managed and controlled by members of the boards on a voluntary basis, not on a full-time basis by professional talents.

The findings do not support H1, however evidence showed that the numbers of board members appointed is positively associated with co-operative size at $1 \%$ significance level as per Table 6 . Hence, it suggests that the larger size a co-operative is, the more likely it is to appoint a bigger sized board. According to Collins et al. (2006) wider board size would lead to more opportunities for networking, bringing more experience, knowledge and skills to improve the strategic decision-making capabilities. Thus, when larger groups reflect how cumbersome decision-making processes can be, perhaps by appointing a bigger board size with more directors to the board, it would enable them to engage their members and stakeholders in the said process as much as possible.

\subsection{Ethnic Diversity}

Second hypothesis $(\mathrm{H} 2)$ predicted that ethnic diversity will positively be associated with co-operative reputation. The regression coefficient $\beta 2(\mathrm{BETH})=0.113$ in Table 7 reveals a positive relationship where larger ethnic diversity will enhance co-operative reputation. Shukeri et al. (2012) gave their reason that multi-racial boards had positively affected firm performance because Malaysia has a multi-racial community where people live and interact well with other people from different ethnic backgrounds. Therefore, it is less probability to cause miscommunication in the management and provide a wider range of information from different ethnic backgrounds among the board members. Despite similar signs observed with the hypothesis developed in $\mathrm{H} 2$, the regression result evidence showed no 
significant association between co-operative reputation and ethnic diversity in the scale population of this study (p-value $=0.474$ more than 0.05). Hence, the insignificant result still leads to the hypothesis being rejected.

This is consistent with the result found by Carter, D'Souza, Simkins, \& Simpson (2010) that there is no significant influence of ethnic minority diversity to firm financial performance among US corporations listed in the S\&P 500 index. They suggested different types of law, geography, historical background, cultural environment and other factors that may affect diversity, in general, and the diversity of the board in particular. In addition, the finding may be explained by low representation of ethnic diversity in co-operatives where 156 out of 183 total observations with about $85 \%$ co-operatives are zero ethnic diversified. The choice of ethnicity diversity as significant dimensions of board characteristics is somewhat unique to the co-operative sector, where most of the board of directors are appointed internally on voluntary basis among co-operative's members (Kasmuri, 2015). Perhaps, it reflects the unique nature of co-operatives which were established based on co-operative's principles and values to achieve the objectives of their common needs among similar community groups and backgrounds.

\subsection{Gender Diversity}

With respect to the third hypothesis (H3), gender diversity is suggested to have positive association on co-operatives reputation in Malaysia. The coefficient results in regression table $\beta 3(\mathrm{BGEN})=-0.037$, reveals a negative relationship that larger female directors on board will depreciate co-operative reputation. However, the test of $\mathrm{H} 3$ provides no evidence of a significant relationship ( $\mathrm{p}$-value $=0.802$ more than 0.05 ) between the numbers of ethnic minority directors on co-operative reputation. Appropriately, it can be explained that the increasing or decreasing of females on the board will not give significant effect to the reputation amongst co-operatives in Malaysia.

The result contradicts to extant empirical studies done by Brammer et al.(2009), Bear \& Post (2010) and Bravo et al.(2015) who found a significant positive relation between gender diversity and corporate reputation. In fact, this is consistent with the result found by Marimuthu \& Kolandaisamy (2009) and Shukeri et al.(2012) reasoning that there is no significant influence of gender diversity to firm performance among public listed companies in Malaysia because it is depending on the respective country laws, historical backgrounds and corporate culture. Carter et al.(2010) also found insignificant evidence of gender diversity to financial performance of all firms listed on the Fortune 500 from 1998 to 2002. He explained the reason why Norwegian boards are more diverse in terms of gender than the US boards due to the existence of specific legislation in Norway that required the composition of $40 \%$ women in the board of directors of the company. The findings can also be denoted by Kramer, Konrad, \& Erkut (2008) suggestion that the appointment of female directors on board does not lead to better reputation because their appointment could be due to lack of a critical mass and tokenism. Perhaps, it may be challenging for the female directors to voice their opinions and to be heard in the strategic decision-making processes on the board in companies as well as in the co-operatives sector.

\subsection{Board Age}

Meanwhile, the fourth hypothesis (H4) proposed that board age is positively associated with the co-operative reputation, which means that the older the average age of the board members, the better reputation the co-operatives would have with respect to the Top 100 Co-operatives Index. Table 7 shows the regression coefficient result $\beta 4$ $(B A G E)=0.185$, reveals direction of relationship as predicted that directors on greater average age or older directors will enhance the co-operatives reputation. Perhaps, older directors provide wisdom and better consultation as compared to young directors who may be dynamic, innovative and full of ideas but may lack work experiences(Abdullah \& Ku Ismail, 2013). However, p-value $=0.424$ of board age is more than 0.05 significant level, so the result is weak and statistically insignificant to provide evidence of its linear relationship.

Therefore, $\mathrm{H} 4$ is not supported which can be explained that the increasing or decreasing on the average age of board members will not give significant effect to the reputation amongst co-operatives in Malaysia. This finding is consistent with Cambrea et al.(2017) who found that insignificant effect of TMT's age heterogeneity on firm performance but inconsistent with those studies conducted by Abdullah \& Ku Ismail (2013) and Duc \& Thuy (2013). Both of the latter studies found evidence on the effects of board age and firm performance of public listed companies in Malaysia and Vietnam. Even though it is found that the average age of directors on board is not significantly associated with the co-operative reputation, the result of correlation coefficient in Table 6 indicates that board age is negatively associated with the proportion of female directors on the board at $1 \%$ significant level. Hence, it identifies the effect on the reputation of the co-operatives by older directors on the board, is largely attributed to fewer proportion of female directors in co-operatives. It suggests that the larger the proportion of female directors is, the more likely it is to appoint younger age of board members in a co-operative. 


\subsection{Education Diversity}

The empirical studies found that in the educational background of board and top management executives, it is positively related to firms' financial performance. Finally, the fifth hypothesis (H5) is proposed that higher education among the board leads to better reputation of co-operatives with respect to the Top 100 Co-operatives Index. Table 7 shows the regression coefficient result $\beta 5(\mathrm{BEDU})=0.265, \mathrm{t}$-value $=2.190$ and $\mathrm{p}$-value $=0.03$ less than 0.05 significant level. Since the p-value of education diversity is in the rejection region, it indicates a significant positive linear relationship so that the null hypothesis is rejected. Thus, the regression results supported H5 which can be explained that the greater proportion of education diversity on the board will significantly lead to better reputation amongst co-operatives in Malaysia.

The acceptance of H5 indicates consistency with performance antecedents that directors or executives with high educational background such as Master and $\mathrm{PhD}$ is generally related to a variety of perspectives, cognitive resources and skill sets (Cambrea et al., 2017; Carpenter et al., 2004; Darmadi, 2013; Hambrick et al., 1996). Perhaps, it can be explained that heterogeneity in education offers competitive advantage which is beneficial in problem-solving and improve the strategic decision-making processes on the board that leads to superior firm performance. It also extends the finding of Fombrun (1996) into the co-operatives sector, which suggested that greater firm performance attributes to better reputation in the eyes of the stakeholders. With the respect of H5 findings, it opposed findings by (Adnan et al., 2016; Duc \& Thuy, 2013) who found insignificant effect of education diversity on the board towards firm performance. Adnan et al. (2016)further discussed that education diversity in Malaysian board would diminish firms' performance especially in GLCs because their culture in appointing directors are based on networking attributes instead of educational backgrounds.

\section{Conclusion}

This study examines the relationship between corporate governance mechanism, specifically board characteristics and co-operatives reputation in Malaysia. Numerous literatures and empirical studies on corporate governance theory proposed that boards structure plays an important role in the governance of any organizations; which according to Fama \& Jensen (1983) the board is crucial for strategic decision making, setting objectives, monitoring and controlling the firm's activities. Extant empirical studies highlighted the ability of firms to control firm resources that potentially provide sustained competitive advantage (Barney, 1991; Wernerfelt, 1984) which consequently leads to better performance (Barney, 2001; Bridoux, 2004; Orlando, 2000) and firms' success (Galbreath, 2005). Therefore, in considering the idiosyncratic and heterogenous in firm resources as fundamental perspective in explaining why some firms are superior compared to others, the Resource Based View posits such a position.

What more, this study provides an insight and ideas for co-operators and practitioners in co-operative societies to consider corporate governance antecedents in improving co-operative's values and indirectly help the government in achieving the national economic goals. Fombrun \& Shanley (1990) claimed that great reputation can obtain a competitive advantage which would enable corporations to charge premium prices for products, attract best talents, attain favourable financial arrangements, and ease relationship with customers plus benefit from greater freedom in decision making. In order to obtain the stakeholders' confidence and to sustain business activities, the co-operatives need to enhance their reputation by disseminating the latest information and communicating their achievements, profitability and commitment towards social performance.

In posit of the RBV approach, the practitioner can fully utilise their internal resources which is board capabilities to obtain sustained competitive advantage among their competitors. Through this study, the co-operator and practitioner may identify the appropriate governance determinants that may influence the reputation of co-operatives in Malaysia, specifically on board of director's factors. Ultimately, this study will hopefully be important for the policy makers such as the government and regulatory bodies in strengthening policy consideration regarding governance mechanism to stimulate performance and sustained competitive advantage among co-operatives in Malaysia.

\section{Acknowledgement}

We wish to thank the Institute of Quality and Knowledge Advancement and the Institute of Research Management and Innovation of Universiti Teknologi MARA for their support and funding.

\section{References}

Abdulazeez, D. A., Ndibe, L., \& Mercy, A. M. (2016). Corporate Governance and Financial Performance of Listed Deposit Money Banks in Nigeria. Journal of Accounting \& Marketing, 5(1), 1-6. https://doi.org/10.4172/2168-9601.1000153

Abdullah, S. N., \& Ku Ismail, K. N. I. (2013). Gender, ethnic and age diversity of the boards of large Malaysian 
firms and performance. Jurnal Pengurusan, 38, 27-40. Retrieved from https://ssrn.com/abstract=2944876

Adnan, M. F., Sabli, N., Rashid, M. Z. A., Hashim, A., Paino, H., \& Abdullah, A. (2016). The impact of educational level of board of directors on firms' performance. Regional Conference on Science, Technology and Social Sciences (RCSTSS 2014), 37-48.

Al-Baidhani, A. M. (2014). The Role of Audit Committee in Corporate Governance: Descriptive Study. SSRN Electronic Journal, 1-25. Retrieved from http://www.ssrn.com/abstract $=2487167$

Barnett, M. L., Jermier, J. M., \& Lafferty, B. A. (2006). Corporate Reputation: The Definitional Landscape. Corporate Reputation Review, 9(1), 26-38.

Barney, J. (1991). Firm Resources and Sustained Competitive Advantage. Journal of Management, 17(1), 99-120.

Barney, J. (2001). Resource-based theories of competitive advantage: A ten-year retrospective on the resource-based view. Journal of Management, 27, 643-650.

Barrett, A. (2017). Age diversity within boards of directors of the S\&P 500 companies. Retrieved from www.irrcinstitute.org

Bear, S., \& Post, C. (2010). The Impact of Board Diversity and Gender Composition on Corporate Social Responsibility and Firm Reputation. Journal of Business Ethics, 97, 207-221.

Bidin, Y. H. (2007). Positioning Knowledge Management As Key Success Factor in the Growth of Cooperatives in Malaysia. Asian Academy of Management Journal, 12(1), 69-82.

Boyd, B. K., Bergh, D. D., \& Ketchen, D. J. (2010). Reconsidering the Reputation-Performance Relationship: A Resource-Based View. Journal of Management, 36(3), 588-609.

Brammer, S., Millington, A., \& Pavelin, S. (2007). Gender and ethnic diversity among UK corporate boards. Corporate Governance: An International Review, 15(2), 393-403.

Brammer, S., Millington, A., \& Pavelin, S. (2009). Corporate reputation and women on the board. British Journal of Management, 20(1), 17-29.

Bravo, F., Abad, C., \& Briones, J. L. (2015). The board of directors and corporate reputation : an empirical analysis. Academia Revista Latinoamericana de Administración, 28(3), 359-379.

Bridoux, F. (2004). A resource-based approach to performance and competition: an overview of the connections between resources and competition. Luvain, Belgium Institut et de Gestion, Universite Catholique de Louvain, (1984), 1-21. Retrieved from http://www.uclouvain.be/cps/ucl/doc/iag/documents/WP_110_Bridoux.pdf

Cambrea, D. R., Lussana, G., Quarato, F., \& Capello, P. V. (2017). Top management team diversity and firm performance: Empirical evidence from the fashion and luxury industry. Corporate Ownership \& Control, 15(1-2), 325-340.

Carpenter, M. A., Geletkanycz, M. A., \& Sanders, W. G. (2004). Upper echelons research revisited: Antecedents, elements, and consequences of top management team composition. Journal of Management, 30(6), 749-778.

Carpenter, M. A., \& Westphal, J. D. (2001). The strategic context of external network ties: Examining the impact of director appointments on board involvement in strategic decision making. ® Academy of Management Journal, 4(4), 639-660.

Carter, D. A., D'Souza, F., Simkins, B. J., \& Simpson, W. G. (2010). The gender and ethnic diversity of US boards and board committees and firm financial performance. Corporate Governance: An International Review, 18(5), 396-414.

Ching Choo Huang, Suhana Zazale, Rohana Othman, Nooraslinda Abdul Aris, \& Siti Maznah Mohd Ariff. (2015). Influence of Cooperative Members' Participation and Gender on Performance. Journal of Southeast Asian Research, 2015, 1-9.

Chronology of The Co-Operative Movement. (n.d.). Retrieved October 22, 2018, from https://www.skm.gov.my/index.php/en/mengenai-skm/gerakan-koperasi/pengenalan/kronologi-gerakan-koperasi

Co-operative Societies Act 1993. (2015). Malaysia.

Collins, D. W., LaFond, R., \& Ashbaugh-Skaife, H. (2006). The effects of corporate governance on firms' credit ratings. Journal of Accounting and Economics, 42, 203-243.

Darmadi, S. (2013). Board members' education and firm performance: evidence from a developing economy. 
International Journal of Commerce and Management, 23(2), 113-135.

Duc, V., \& Thuy, P. (2013, October). Corporate governance and firm performance: empirical evidence from vietnam. Journal of Economic Development, 218, 62-77.

EFama, \& Jensen, M. C. (1983). Agency problems and residual claims. Journal of Law and Economics, 26(2), 327-349.

Fombrun, C. (1996). Reputation: Realizing Value from the Corporate Image. Harvard Business School Press, Boston, MA.

Fombrun, C., \& Shanley, M. (1990). What's in a Name? Reputation Building and Corporate Strategy. Academy of Management Journal, 33(22), 233-258.

Fryxell, G. E., \& Jia Wang. (1994). The Fortune Corporate "Reputation" Index: Reputation for What? Journal of Management, 20(1), 1-14. Retrieved from http://journals.sagepub.com/doi/10.1177/014920639402000101

Galbreath, J. (2005). Which resources matter the most to firm success? An exploratory study of resource-based theory. Technovation, 25(9), 979-987.

García-Meca, E., \& Palacio, C. J. (2018). Board composition and firm reputation: The role of business experts, support specialists and community influentials. BRQ Business Research Quarterly, 21(2), 111-123. https://doi.org/10.1016/j.brq.2018.01.003

GP27: Garis Panduan Tadbir Urus Koperasi. (2015). Malaysia Co-operative Societies Commission. Retrieved from https://www.skm.gov.my/images/images/Garis-Panduan/GP27-Garis-Panduan-Tadbir-Urus-Koperasi.pdf

GP3: Garis Panduan Pelantikan Atau Pelantikan Semula Anggota Lembaga Koperasi (Pindaan). (2012). Malaysia $\begin{array}{llll}\text { Co-operative } & \text { Societies } & \text { Commission. } & \text { Retrieved }\end{array}$ https://www.skm.gov.my/images/images/Garis-Panduan/GP03.pdf

Hambrick, D. C., Cho, T. S., \& Chen, M.-J. (1996). The influence of top management team heterogeneity on firms' competitive moves. Administrative Science Quarterly, 41(4), 659-684.

Jensen, M. C. (1993). The modern industrial revolution, exit, and the failure of internal control systems. The Journal of Finance, 48(3), 831-880.

Kasmuri, N. (2015, November). Governance : Issues and Challenges in Malaysian C0-Operative Movement. Dimensi Koop, 47, 4-10. Retrieved from http://www.mkm.edu.my/images/Awam/Penerbitan/Dimensi_Koop/Dimensi_Koop47/governance-issues-and-c hallenges-in-malaysian-co-operative-movement.pdf

Kitchen, P. J., \& Laurence, A. (2003). Corporate Reputation: An Eight-Country Analysis. Corporate Reputation Review, 6(2), 103-117.

Kline, R. B. (1998). Principles and Practice of Structural Equation Modelling. The GuilFord Press. New York: The Guilford Press.

Kramer, V. W., Konrad, A. M., \& Erkut, S. (2008). Critical mass on corporate boards: Why three or more women enhance governance. Organizational Dynamics, 37(2), 145-164.

Kumaran, V., \& Thenmozhi, R. (2016). Impact of Corporate Governance on Corporate Reputation. International Journal of Management and Commerce Innovations, 3(2), 1-8. Retrieved from http://ijrcm.org.in/article_info.php?article_id=5988

Lipton, M., \& Lorsch, J. W. (1992). A modest proposal for improved corporate governance. The Business Lawyer, 59-77.

Mahajar, A. J., \& Mohd Yunus, J. (2005). Internationalisation of Kedah's Cooperative Societies. Problems and Perspectives in Management, 3(4), 44-55.

Mahazril'Aini, Y., Hafizah, H. A. K., \& Zuraini, Y. (2012). Factors Affecting Cooperatives Performance in Relation to Strategic Planning and Members Participation. Procedia -Social and Behavioral Sciences, 65, 100-105.

Malaysia Co-operative Societies Commission. (2018). Co-operative Movement Statistics Year 2017. Kuala Lumpur: Malaysia Co-operative Societies Commission. Retrieved from https://www.skm.gov.my/images/images/Statistik-Gerakan-Koperasi/Statistik-Tahunan/statistic-tahunan-2017/ Buku Perangkaan Gerakan Koperasi Malaysia 2017.pdf

Marimuthu, M., \& Kolandaisamy, I. (2009). Can demographic diversity in top management team contribute for 
greater financial performance? An empirical discussion. The Journal of International Social Research, 2(8), 273-286.

Mayo, E. (2011). Co - operative performance. Sustainability Accounting, Management and Policy Journal, 2(1), $158-164$.

Mohamad, M., \& Othman, I. W. (2013). Reputation and Transparency of Cooperative Movement in Malaysia. International Scholarly and Scientific Research \& Innovation, 7(8), 2281-2284.

Mohamad, M., Othman, I. W., \& Mohamed, A. (2013). Accountability Issues and Challenges: The Scenario for Malaysian Cooperative Movement. International Journal of Economics and Management Engineering, 7(6), 1503-1508. https://doi.org/scholar.waset.org/1999.10/1437

Musteen, M., Datta, D. K., \& Kemmerer, B. (2010). Corporate reputation: Do board characteristics matter?. British Journal of Management, 21, 498-510.

National Co-operative Policy 2011-2020. (2011). Malaysia Co-operative Societies Commission.

Orlando, C. R. (2000). Racial diversity, business strategy, and firm performance: A resource-based view. Academy of Management Journal, 43(2), 164-177.

Pallant, J. (2007). SPSS Survival Manual: a Step by Step Guide to Data Analysis Using SPSS Version 15 (3rd ed.). Berkshire, England: Mc Graw Hill.

Rohana Othman, Roshayani Arshad, Nooraslinda Abdul Aris, \& Siti Maznah Mohd Arif. (2015). Organizational Resources and Sustained Competitive Advantage of Cooperative Organizations in Malaysia. Procedia - Social and Behavioral Sciences, 170, 120-127.

Rohana Othman, Roslani Embi, Nooraslinda Abdul Aris, Siti Maznah Mohd Arif, Huang Ching Choo, \& Norashikin Ismail. (2016). Board Governance and Performance: An Exploratory Study of Malaysian Cooperative Organizations. Journal of Southeast Asian Research, 2016, 1-12.

Security Commission Malaysia. (2017). Malaysian Code of Corporate Governance. Kuala Lumpur: Security Commission Malaysia.

Sekaran, U., \& Bougie, R. (2016). Research Methods For Business: A Skill Building Approach (7th ed.). John Wiley $\&$ Sons.

Shahwan, T. M. (2015). The effects of corporate governance on financial performance and financial distress: evidence from Egypt. Corporate Governance: The International Journal of Business in Society, 15(5), 641-662.

Shamsuddin, Z. (2015). The Efficacy Impact of Corporate Governance Compliance on the Financial Performance of Cooperative. In International Organization for Research and Development (pp. 1-8). Retrieved from https://pdfs.semanticscholar.org/81ec/40cf1e22bc067759937e1cd1e4cb31c5d06d.pdf

Shamsuddin, Z., Ismail, A. G., Mahmood, S., \& Yusoff, W. S. (2017). The Effect of Capital Structure on Credit Cooperative's Performance in Malaysia. World Applied Sciences Journal, 35(9), 1965-1970.

Shukeri, S. N., Shin, O. W., \& Shaari, M. S. (2012). Does Board of Director's Characteristics Affect Firm Performance? Evidence from Malaysian Public Listed Companies. International Business Research, 5(9), 120-127.

Tabachnick, B. G., \& Fidell, L. S. (2007). Using Multivariate Statistics (5th ed.). USA: Pearson Education Inc.

Top 100 Co-operatives in Malaysia. (2017). Malaysia Co-Operative Societies Commission. Malaysia Co-operative Societies Commission. Retrieved from https://www.skm.gov.my/index.php/en/component/flippingbook/book/45/Array?page=141

Wernerfelt, B. (1984). A resource - based view of the firm. Strategic Management Journal, 5, 171-180.

Wiedmann, K.-P., \& Buxel, H. (2005). Corporate Reputation Management in Germany: Results of an Empirical Study. Corporate Reputation Review, 8(2), 145-163.

Yadav, B. (2013). Creative Accounting: A Literature Review. Industrial, Financial \& Business Management (IFBM), 1(5), 181-193.

Zaridis, A. D., \& Mousiolis, D. T. (2014). ScienceDirect Entrepreneurship and SME's Organizational Structure. Elements of a Successful Business. Procedia - Social and Behavioral Sciences, 148, 463-467. 